\author{
Witold Brostow ${ }^{1}$, Kevin P. Menard ${ }^{1,2}$ and Noah Menard ${ }^{1,3}$
}

\title{
COMBUSTION PROPERTIES OF SEVERAL SPECIES OF WOOD
}

\author{
${ }^{1}$ Laboratory of Advanced Polymers \& Optimized M aterials (LAPOM), Department of M aterials Science \\ and Engineering, University of N orth Texas, 1150 Union Circle 305310, Denton, \\ TX 76203-5017, USA; wbrostow@yahoo.com; http:/ / www.unt.edu/ LAPOM / \\ 2 PerkinElmer Life Sciences, Shelton, CT 06484-4794, USA; kmenard@gmail.com \\ ${ }^{3}$ Liberty Christian High School, Argyle, TX, USA; nrcmenard@gmail.com
}

Received: April 15, 2009

(C) Brostow W., Menard K., Menard N., 2009

\begin{abstract}
Six species of wood were studied by combined thermogravimetric and differential thermal analysis (TG/ DTA) so as to evaluate their combustion properties in terms of the amount of energy released, the initial temperature of ignition, and the cleanness of burning. Pinus monticola, Acer saccharum, Quercus rubra, Diospyrus spp., Tabebuia spp. and Guaiacum spp. were chosen to provide a wide range of hardness values and densities. Quercus rubra burned to the hottest temperature of the samples, and also left the least amount of ash behind. For Guaiacum spp. its burning temperature is in the middle of the peak temperatures for other woods - while its final amount of ash is considerably larger than in the other samples. There is no connection between the wood density and the parameters characterizing the burning process.
\end{abstract}

Keywords: wood, burning temperature, enthalpy of combustion, ash formation, thermogravimetric analysis, differential thermal analysis.

\section{Introduction}

Wood has been extensively studied because of its use as a construction material [1-3] and as fuel source [4]. Combustion properties of wood are also important because of safety issues since it is one of the more commonly available flammable materials. Its combustion process is well studied $[5,6]$ particularly so for modified woods which have been treated to resist burning [7-9]. Untreated wood have also been studied, most commonly as a fuel source [10]. Differential thermal analysis (DTA) and thermogravimetric analysis (TGA) have been used to look at the effect of oxygen levels [11] on combustion. The two techniques have been described by one of the present authors [12] and also by Lucas and her colleagues [13]. In addition, specific species such as birch [14], olive [15], oak [16], willow [17], and pine species [18] have been investigated.
Wood species show tremendous variation in physical and mechanical properties [19]. Moreover, culinary studies report significant differences in wood used for smoking of food products [20]. Our work looks at the composition properties of untreated wood by species - to see whether the natural variation in wood has any significant effects on the combustion properties.

\section{Experimental}

Wood species were selected on the basis of hardness and oil content to cover a range of properties. Pinus monticola, Acer saccharum, Quercus rubra, Diospyrus spp., Tabebuia spp. and Guaiacum spp. were chosen to represent a range of wood strengths and properties as described by Vangaard [1]. All samples were air dried to $12 \pm 2 \%$ humidity, as measured using an electronic humidity meter. Samples were prepared by removing small shaving of the wood with a plane. Attempts to use ground samples were unsatisfactory due to the weight losses caused by the nitrogen purge.

5-10 milligrams of each species were studied using a PerkinElmer Diamond Thermo-gravimetric/ Differential Thermal Analyzer (TG/DTA). The analyzer was calibrated using indium, aluminum, and gold standards and the calibration checked using calcium oxalate. All calibrations and checks were run at $10 \mathrm{~K} \cdot \mathrm{min}^{-1}$ and $200 \mathrm{cc} \cdot \mathrm{min}^{-1}$ air purge. Samples of each species were run three different times. The samples were loaded into unsealed alumina crucibles, and were run from beginning at room temperature up to $1273 \mathrm{~K}$ at the rate $10 \mathrm{~K} \cdot \mathrm{min}^{-1}$ with a $200 \mathrm{cc} \cdot \mathrm{min}^{-1}$ purge rate. Dry air was used as the purge gas. After the run was completed, the starting temperature that it began to burn, the energy released while burning (enthalpy of combustion $H^{c o m b}$ ) and the amount of ash left were calculated. 


\section{Results and Discussion}

A representative DT/TGA trace is shown in Fig. 1. Comparisons of the TGA curves are shown as an overlay in Fig. 2. DTA data is shown overlaid in Fig. 3. The averaged results for all 7 species are reported in Table 1.

On completing all runs, a white ash remained in the pan. Several events are seen in each material in the TGA results. First, depending on the amount of water and oil in the sample, a small percentage of the total weight would be evaporated. Interestingly, in no case did this amount correspond to the approximate $10 \%$ moisture detected by the electronic humidity meter. We infer that this water is trapped in the fibers and released during the burn. As the temperature rose, the main body of the wood ignited, leaving a small amount of ash seen in the pan. Ignition temperature appeared to bear no relationship to the wood density in either the DTA or TGA experiments. Ash remaining, a measure of the inorganic material in the specimen was similarly unrelated to density; see Fig. 4.

The species of the wood does have an effect on the combustibility of the sample but it does not appear to be related to density. Quercus rubra burned to the hottest temperature of the samples, and also left the least amount of ash behind.

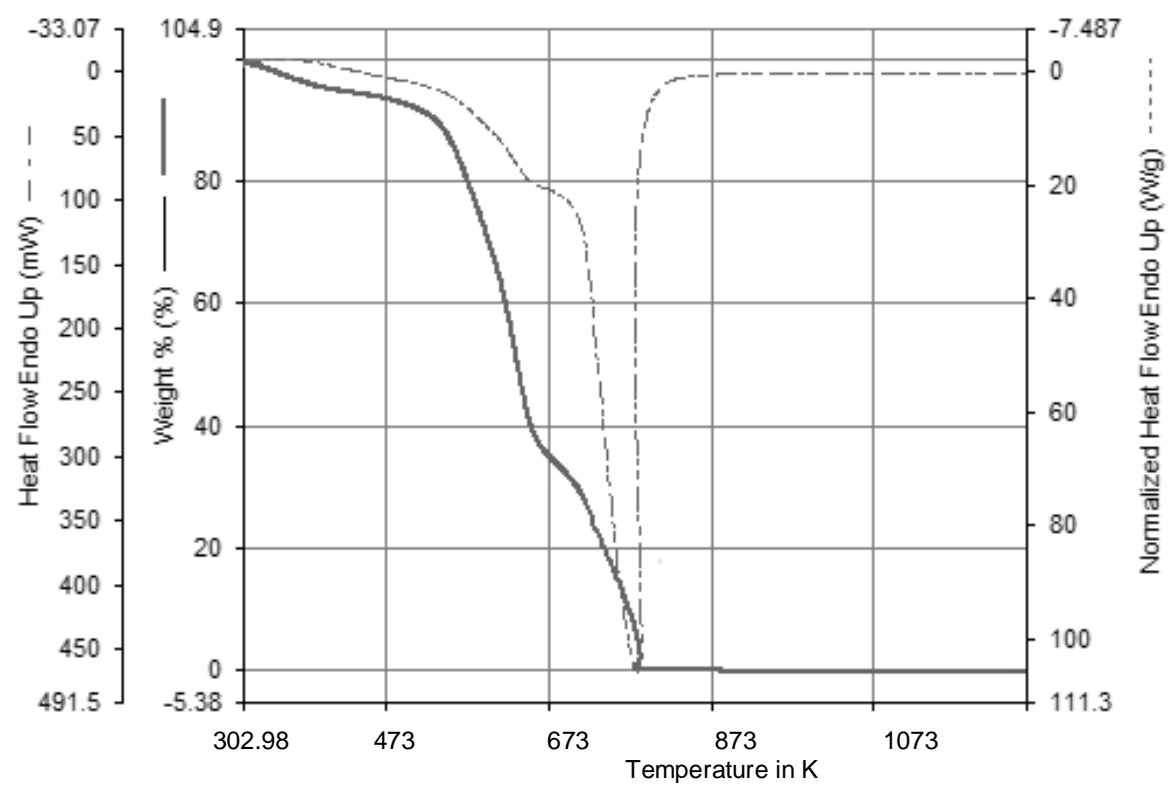

Fig. 1. An example of the TG/DTA scan, showing the relationship of the DT and TGA data

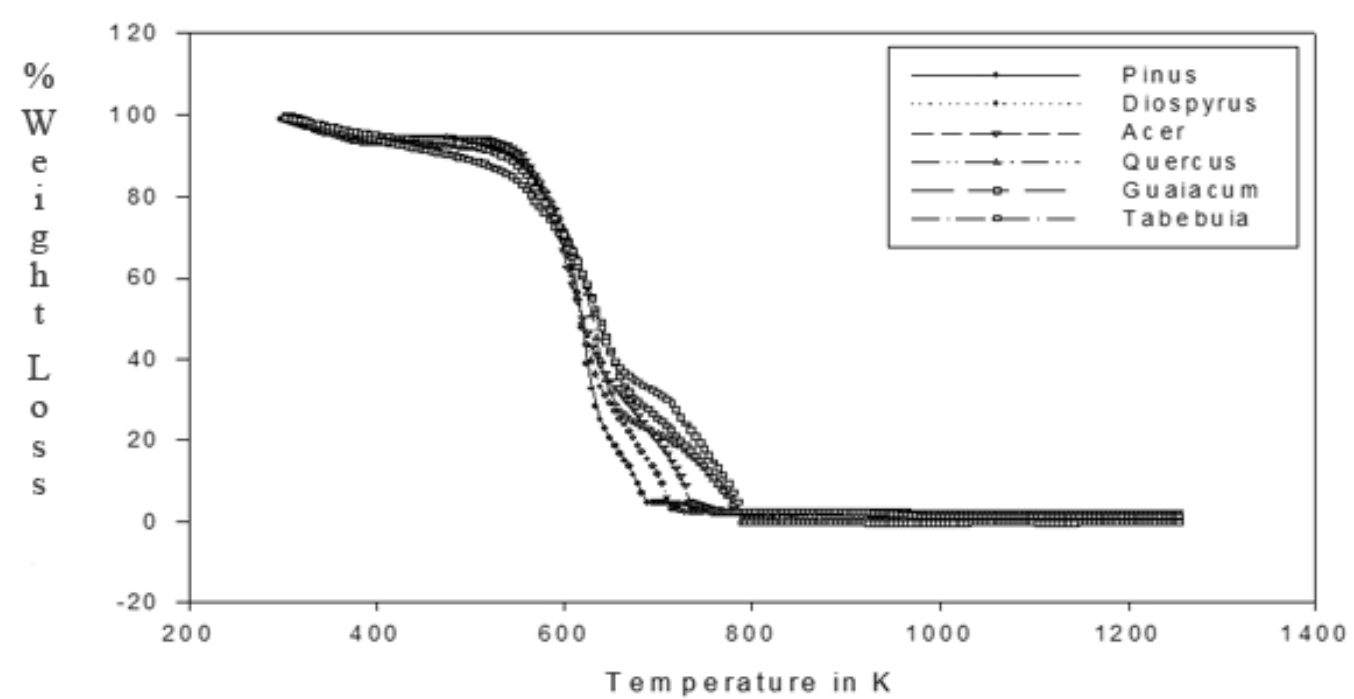

Fig. 2. Overlay of TGA curves for all species of wood, showing the multiple weight losses discussed below 


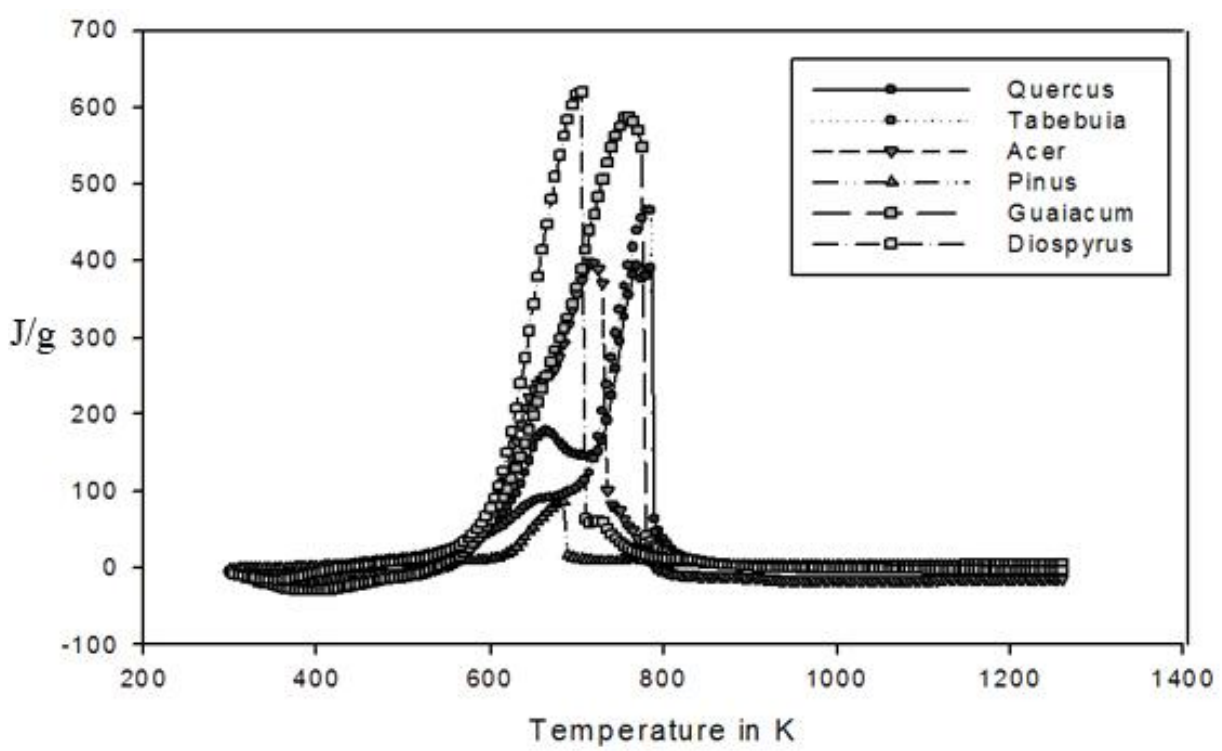

Fig. 3. Overlay of DTA curves for all seven species of wood, showing the multiple energetic events discussed below. Curves show the normalized heat flow for the samples

Table 1

Results from all seven species of wood

\begin{tabular}{|c|c|c|c|c|c|c|c|c|c|}
\hline $\begin{array}{c}\text { Common } \\
\text { Name }\end{array}$ & Species & $\begin{array}{c}\text { Density } \\
\mathrm{d}(\mathrm{dry}), \\
\mathrm{kg} / \mathrm{m}^{3}\end{array}$ & $\begin{array}{c}\text { TGA } \\
\text { water, } \\
\%\end{array}$ & $\begin{array}{c}\text { TGA } \\
\text { burn } \\
\text { onset, } \mathrm{K}\end{array}$ & $\begin{array}{c}\text { TGA } \\
\text { loss, } \\
\%\end{array}$ & $\begin{array}{c}\text { TGA } \\
\text { ash, } \\
\%\end{array}$ & $\begin{array}{c}\text { DTA } \\
\text { onset, } \\
\mathrm{K}\end{array}$ & $\begin{array}{c}\text { Enthalpy of } \\
\text { combustion, } \\
\mathrm{J} / \mathrm{g}\end{array}$ & Peak, K \\
\hline Pine & Pinus monticola & 450 & 5.6 & 278.6 & 92.9 & 1.7 & 274.7 & -9953.3 & -9680.3 \\
\hline Maple & Acer saccharum & 720 & 5.4 & 278.4 & 92.7 & 1.7 & 274.7 & -8603.3 & -8330.3 \\
\hline Oak & Quercus rubra & 770 & 5.8 & 277.8 & 92.5 & 0.6 & 273.6 & -6826.7 & -6553.7 \\
\hline $\begin{array}{c}\text { East Indian } \\
\text { Rosewwod }\end{array}$ & Diospyrus spp. & 1170 & 6.5 & 279.5 & 92.3 & 1.3 & 274.2 & -11160 & - \\
\hline Ipe & Tabebuia spp. & 1200 & 5.6 & 278.4 & 92.9 & 0.9 & 273.9 & -9806.7 & -9533.7 \\
\hline Lignum Vitae & Guaiacum spp. & 1230 & 5.1 & 277.4 & 91.9 & 2.7 & 275.3 & -7166.7 & -6893.7 \\
\hline
\end{tabular}

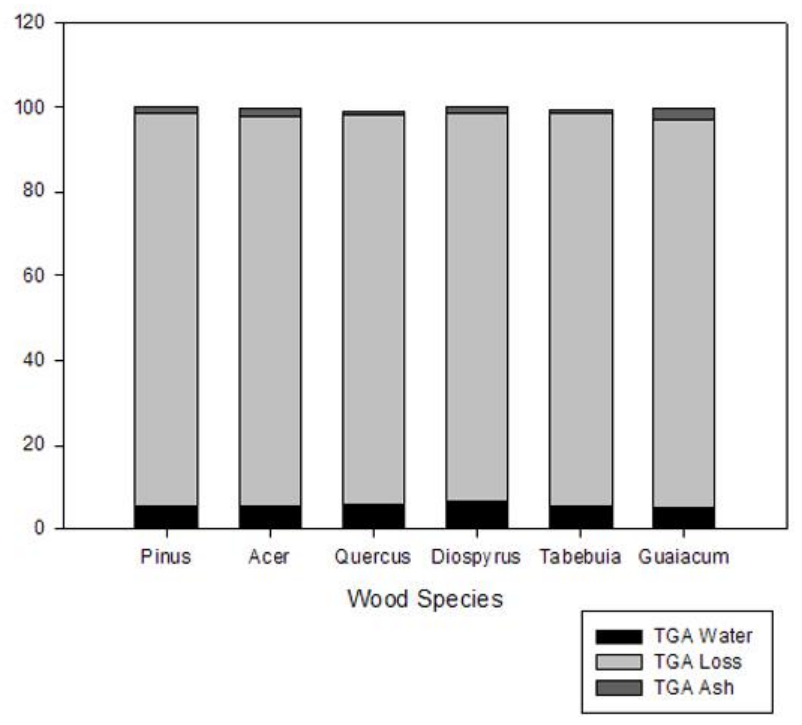

Fig. 4. TGA data according to species

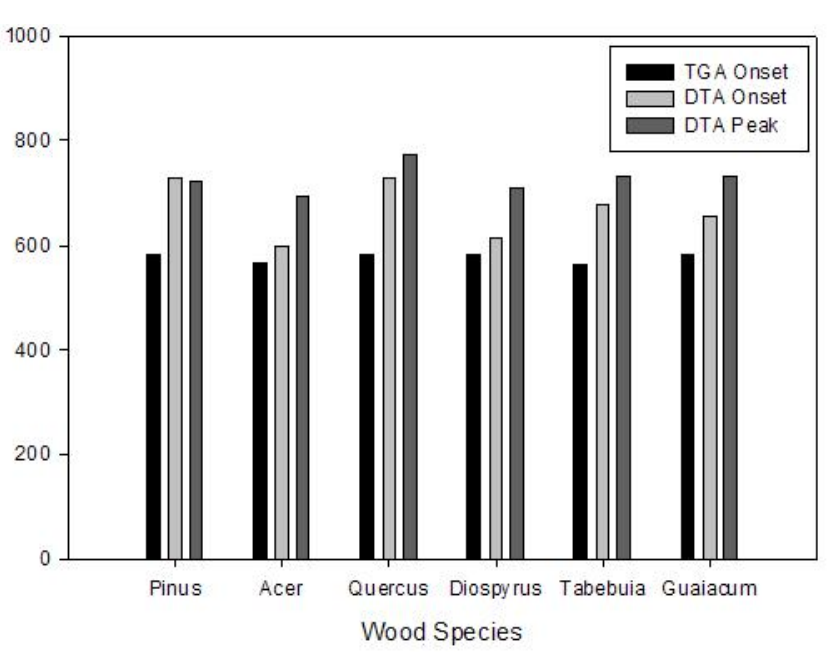

Fig. 5. TGA data according to species 
While Guaiacum spp. burning temperature was in the center of the other samples peak temperatures, the final amount of ash was considerably more than in the other samples.

Similarly in the DTA, corresponding events are seen when each material was ignited. DTA onsets tended to be higher than TGA in all cases and neither the onset nor the peak values of species on burning showed any relationship to the material density.

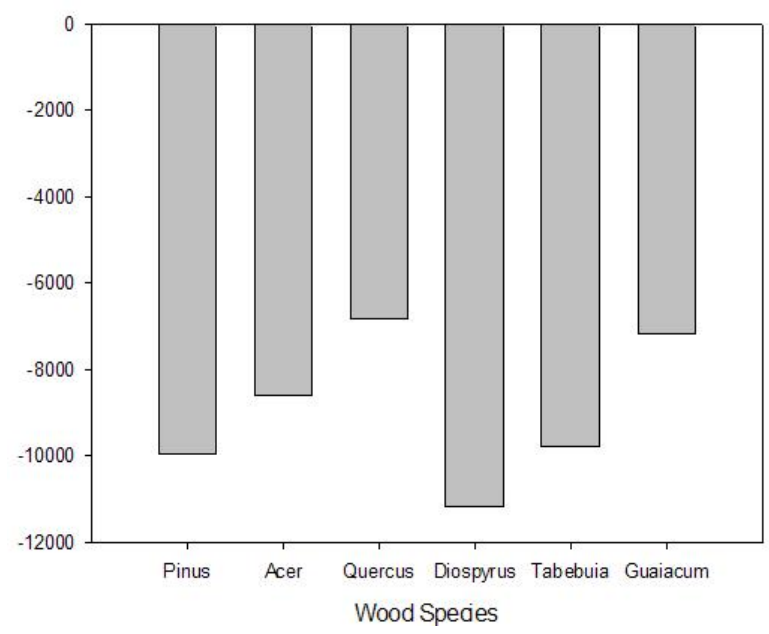

Fig. 6. Enthalpies of combustion

We also display the enthalpies of combustion in Figure 6. As an example, Fig. 6 tells us that oak wood releases less energy (has smaller enthalpy of combustion) than the other kinds of wood.

\section{Conclusions}

Quercus rubra burned to the hottest temperature among all the samples, and also left the least amount of ash behind. This while for Guaiacum spp. the burning temperature is in the middle of the peak temperatures for other samples; at the same time, the final amount of ash is considerably larger than for the other samples.

Finally, we recall that wood is the most widely used natural composite. Its role does not seem to be limited by the growing use of synthetic composites [21].

\section{Acknowledgements}

One of the authors (N.Mernard) would like to thank Ms. Helen Lytle of Liberty Christian School for her help and advice. This work was initially performed as part of the Intel Science Fair Competition.

\section{References}

[1] Wangaard F. (ed.): Wood: its structure and properties. Materials Research Laboratory, The Pennsylvania State University, University Park, Pennsylvania 1981.
[2] Blomquist R. et al. (eds.): Adhesive bonding of wood and other structural materials. Materials Research Laboratory, The Pennsylvania State University, University Park, Pennsylvania 1983. [3] Freas A. (ed.): Wood: Engineering design concepts. Materials Research Laboratory, The Pennsylvania State University, University Park, Pennsylvania 1986.

[4] Ragland K., Aerts D. and Baker A.: Bioresource Techn., 1991, 37, 161.

[5] Beall F. and Eickner H.: Forest Products, Lab Report 141700, Madison, WI, 1970.

[6] Nyuyen T., Zavarin E. and Barrall E.: J. Macromol. Sci. Rev., 1981, C21, 1.

[7] Helsen L. van den Bulck E., Mullens S. and Mullens J.: J. Anal. Appl. Pyrolysis, 1999, 52, 65.

[8] Gao M., Sun C. and Wang C.: J. Thermal Anal. Calorimetry, $2006,85,765$.

[9] Nyuyen T., Zavarin E. and Barrall E.: J. Macromol. Sci. Rev., 1981, C20, 1.

[10] Branca C. and Di Blasi C.: Thermochim. Acta, 2007, 456, 120.

[11] Zayed R., Oren M. and MacKay G.: Fuel, 1987, 66, 116.

[12] Menard K.: Ch. 8 [in:] W. Brostow (ed.) Performance of plastics. Hanser, Munich-Cincinnati 2000.

[13] Lucas E., Soares B. and Monteiro E.: Caracterizacao de Polimeros, e-papers, Rio de Janeiro 2001.

[14] Grioui N., Halouani K., Zoulalain A. and Halouani F.: Thermochim. Acta, 2006, 440, 23.

[15] Bodirlau R., Spiridon I., Teaca C. and Popa I.: Cellul. \& Chem. Techn., 2005, 39, 25.

[16] Janssen F., Prins M. and Ptasinski J.: J. Anal. Appl. Pyrolysis, 2006, 77, 28.

[17] Can K., Fang M., Li S. et al.: Ranshao Kexue Yu Jishu, 2006, 12, 535.

[18] McGee H.: On food and cooking, Collier MacMillan, Toronto 1984.

[19] Hoadley R.: Understanding wood, Taunton Press, Newtown, CT 1980.

[20] Lincoln W. et al.: Encyclopedia of wood. Checkmark Books, New York 1989.

[21] Bunsell A. and Renard J.: Fundamentals of fibre reinforced composite materials, CRC Press, Boca Raton, FL 2005.

\section{ГОРЮЧІ ВЛАСТИВОСТІ ДЕЯКИХ ВИДІВ ДЕРЕВИНИ}

Анотація. 3 використанням термогравиметричного i диференційного термічного методів аналізів вивчено шість зразків деревини. Проведено оцінку їх горючих властивостей, як кількості звільненої енергї, початкової температури займання і чистоти горіння. Pinus monticola, Acer saccharum, Quercus rubra, Diospyrus spp., Tabebuia spp. and Guaiacum spp. було вибрано з огляду забезпечення широкого інтервалу величин густини і твердості. Встановлено, щуо при згорянні Quercus rubra виділяється найбільша теплота і найменша кількість золи. Gиаiасит sрр. має середнє значення температури згоряння серед інших видів деревини, в той час як його зольність суттєво вищза за інші зразки. Показано, шуо між густиною деревини і параметрами, які характеризують проиес горіння, відсутня залежність.

Ключові слова: деревина, температура горіння, ентальпія згоряння, утворення золи, термогравиметричний аналіз, диферениійний термічний аналіз. 